\title{
Promjene režima otjecanja tekućica u gornjem dijelu poriječja Habura u sjeveroistočnoj Siriji u drugoj polovici XX. st. - dio I: godišnji protoci
}

\author{
Danijel Orešić, Georgos Bahnan
}

\begin{abstract}
U članku se razmatraju hidrogeografske prilike i promjene u godišnjim protocima Habura i njegovih pritoka u području Gornje Đezire u sjeveroistočnoj Siriji prema podatcima iz razdoblja 1943.-2001. Istraživano područje žitnica je Sirije. Veliki zahvati u podzemne i površinske vodne resurse počeli su 1970-ih, uglavnom radi natapanja, i doveli su do značajnih smanjenja godišnjih protoka u istraživanom području.
\end{abstract}

Ključne riječi: Sirija, poriječje Habura, godišnji protok

\section{River Regime Changes in the Upper Part of Khabour Catchment Area in North-Eastern Syria in the Second Half of the XXth Century - part I: Annual Runoff}

The papers deals with hidrography of the Upper Jazirah region in north-eastern Syria, particularly with the changes in the mean and annual runoff of the Khabour River and its tributaries in 1943-2001 period. The upper part of the Khabour catchment area is an important Syrian cotton and wheat production area. The use of ground-water and river-water in agriculture, especially since 1970 's lead to significant lowering of the annual runoff of the Khabour and other rivers in the area.

Key words: Syria, Khabour cathment area, annual runoff

\section{UVOD}

Sirija je zemlja heterogenih prirodnih obilježja i složenog društveno-gospodarskog razvitka. Pa ipak, s obzirom na njen geografski položaj i iz njega proizašlu činjenicu da najveći dio zemlje ima polupustinjska obilježja, kao jedan od najvažnijih, zapravo razvojno ograničavajućih čimbenika, javlja se voda u svim svojim pojavnim oblicima. 


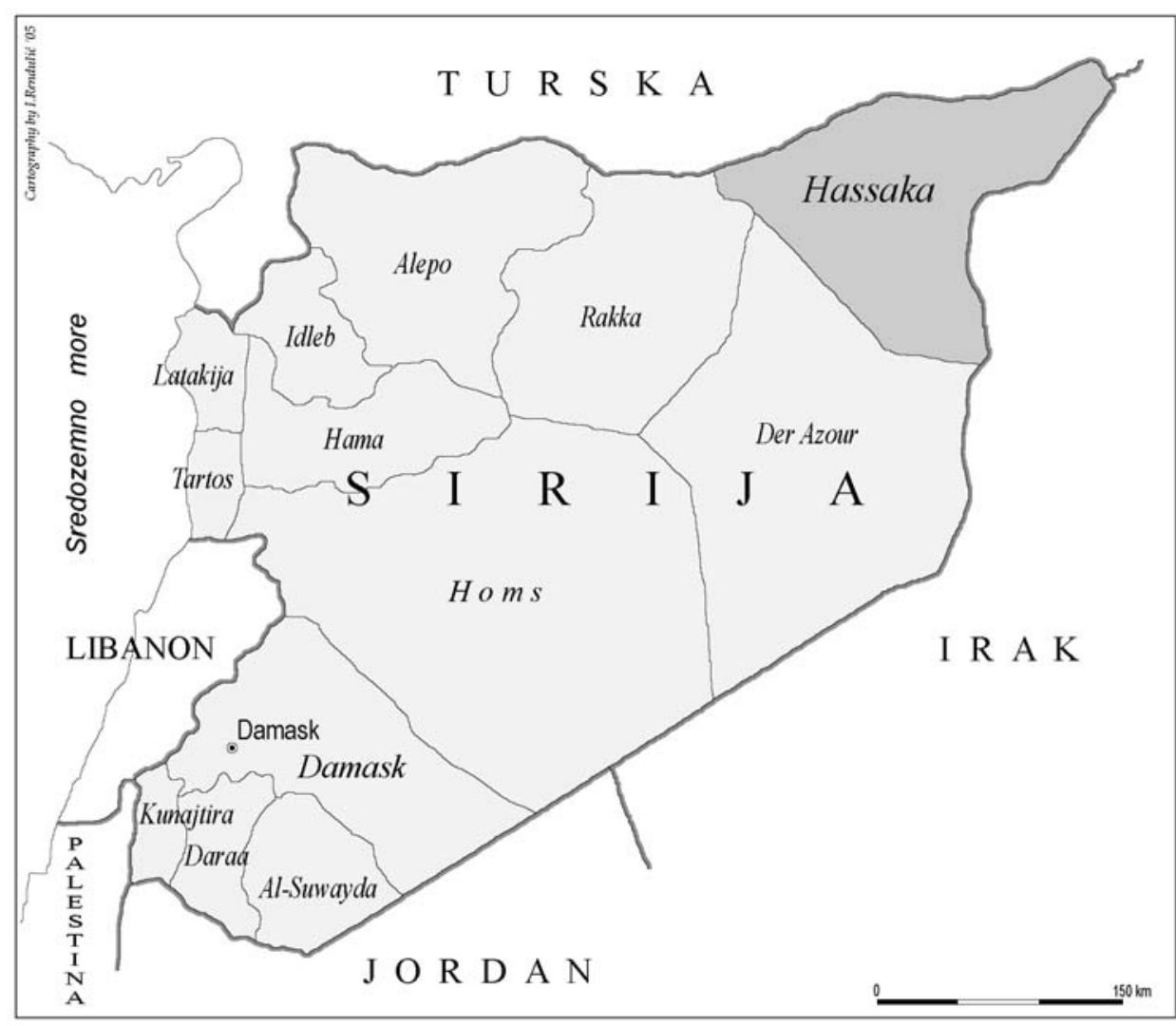

S1. 1. Položaj istraživanog područja u Siriji

Fig. 1 The researched area in Syria

Istraživano područje nalazi se na sjeveroistoku Sirije i jasno je reljefno i hidrografski izdvojen kraj, tradicionalno zvan Gornja Đezira ${ }^{1}$. U reljefnom pogledu to je prostrana zavala između Torosa na sjeveru (u Turskoj) i gorskog niza Abd al Aziz - Sinđar (najveći dio u Iraku) na jugu. Značajno je da su slojevi sinklinale Gornje Đezire nagnuti prema jugu pa podzemne vode s Torosa otječu u tom smjeru. U sklopu zavale Gornje Đezire oblikovana je akumulacija podzemnih voda koje pak rasjedna zona uz sjeverno podnožje planinske strukture Abd al Aziza spriječava u njihovom daljnjem otjecanju prema jugu. Hidrografski to područje pripada razvijenijem, gornjem dijelu poriječja rijeke Habur. Naime, gorski niz Abd al Aziz dijeli poriječje u dva dijela, sjeverniji dio u Gornjoj Đaziri i južniji dio u Donjoj Đaziri. Dio poriječja u Donjoj Đaziri je ravničarski, a Habur polupustinjskim područjem otječe na jug kao alogena tekućica, bez stalnih pritoka, i ulijeva se u Eufrat. Nasuprot tomu u Gornjoj Đaziri litološke i klimatološke prilike pogoduju razmjerno gustoj hidrografskoj mreži. Habur (ime u značenju: izvor plodnosti) je oduvijek bila važna tekućica za natapanje Gornje Đezire. Stanovništvo je uglavnom privlačio njegov sjeverniji dio, pogodan za poljodjelstvo za razliku od južnijeg, sušnijeg dijela, pogodnog za stočarstvo. U Gornjoj Đeziri bujičaste tekućice s Torosa redovito su nakon proljetnih poplava ostavljale plodan mulj koji je svake godine obiljem minerala hranio tlo, dakle, plodno i 
pogodno za poljodjelsku obradu. Treba reći da većina sadašnjih gradova nastaje tek u doba francuske uprave (1920. - 1945.), oko utvrđenih vojarni. Rastakanje tradicionalne agrarne strukture karakterizirane ponajprije autarkičnim i transhumantnim stočarstvom povezanim s plemenskom tradicijom te skromnim samodovoljnim poljodjelstvom počelo je nakon II. svjetskog rata. To je dijelom potaknuto imigracijama arap. stanovništva iz Turske nakon graničnih promjena. Komercijalna poljodjelska proizvodnja razvija se od 1950-ih, uz kreditnu potporu države, a namjesništvo Hassaka ${ }^{2}$, koje se u dobroj mjeri poklapa s istraživanim područjem, prerasta u sirijsku žitnicu već 1960 -ih. U novije doba, ponajviše u posljednjih tridesetak godina počinje značajnija deagrarizacija, razvoj industrije (nafta i plin), te promjene u prostornoj slici naseljenosti. Izgradnjom novih brana i poboljšanom mrežom kanala za natapanje, povećano je obrađeno područje na više od milijun ha, te je danas gornje poriječje Habura glavna sirijska žitnica, vodeće područje sirijske proizvodnje žitarica i važno poljodjelsko područje uzgoja pamuka, sezama i povrća ${ }^{3}$.

Razmjerno brz društveno-gospodarski razvoj, napose razvoj poljodjelstva, doveo je do pretjeranog iskorištavanja prirodno razmjerno obilnih vodnih resursa, što se odrazilo na promjenama u otjecanju površinskih i podzemnih voda. Članak ima za cilj prikazati promjene u režimu otjecanja površinskih voda, poglavito prikazom promjena riječnog režima Habura.

\section{PRETHODNA ISTRAŽIVANJA}

Većina istraživanja u Gornjoj Đeziri bila je geološke i hidrogeološke naravi, a u novije doba ponajprije usmjerena na tehnička rješenja oko dobave vode za potrebe natapanja u namjesništvu Hassaka (brane, bušeni bunari). Tako je mogućnosti iskorištavanja tekućica u sjevernoj Mezopotamiji istraživao Willcocks (1937.). Geološka i hidrografska istraživanja Sirije provodio je L. Dubertret (1933.) što je dovelo do izdavanja (1942.) geološke karte Sirije i Libanona. Opsežnija istraživanje podzemnih voda provodili su D. J. Burdon (1954.), koji je proveo i prva lokalna istraživanja izvora Hol na sjeverozapadu gorja Sinđar(Burdon, 1959.), te sirijac Šafik al Safadi (1960.). Kao početak istraživanja za potrebe FAO Šafik al Safadi i Francis Morte (1963.) opisali su u svom izvještaju važnost vode u gospodarskom razvoju sirijske Đazire. Neovisno od FAO sirijska je vlada (tadašnja Uprava za natapanje Sirije) naručila više studija korištenja voda izvora i tekućica u gornjem toku rijeke Habur: od bugarske tvrtke Bulgarian Agrocomplex Co. (1963., 1976. i 1984.) i švedske tvrtke V.B.B. (1965.). Ministarstvo poljoprivrede naručilo je studiju o zalihama podzemnih voda u namjesništvu Hassaka (Khouri et al., 1965). Godine 1966. FAO je predao Ministarstvu poljoprivrede AR Sirije završni izvještaj, odnosno podrobnu studiju o resursima vode u podzemlju u području sirijske Đezire (sjeveroistočno od Eufrata). Godine 1976. Khouri i Rasoul izradili su manju studiju o vodnim resursima u okolici Kamišlija potrebnim za tadašnji program natapanja novih 1000 ha poljoprivrednog zemljišta u državnom vlasništvu. Od novijih istraživanja u namjesništvu Hassaka ističe se interni izvještaj Ministarstva poljoprivrede Sirije iz 1997. godine.

Geografskih radova koji se odnose na istraživano područje ima vrlo malo. Jedinu regionalnogeografsku studiju pod nazivom Sirijska Đezira (Al Jazira as Syria) napisao je Bogosijan (Boghossian, 1952.) za svoj doktorat iz geografije. Mardini je 1986. godine objavio popularnu knjigu koja daje opći prikaz namjesništva Hassaka. Pretežno 
demogeografski rad koji se odnosi na sjeveroistočni dio namjesništva Hassake objavio je G. Bahnan (1991.). Opsežna geografska istraživanja obavio je sirijski akademik Abd al Salam, koji je od 1980. do 1990. godine objavio u četiri sveska svoje djelo Geografija Sirije. Područje Hassake obrađeno je u posljednjem, 4. svesku, objavljenom 1990. godine. Akademik Abd Rahman Hamida, po specijalnosti hidrogeograf, iako nije pisao posebno o namjesništvu Hassaka, objavio je od 1960-ih godina na ovamo niz radova od kojih se neki dotiču hidrogeografske situacije u namjesništvu Hassaka. Posebno se ističe njegovo istraživanje jezera Hatunija. Od autora iz ostalih geografskih disciplina koji se u svojim radovima jednim svojim dijelom odnose na područje ili djelatnosti u namjesništvu Hassaka izdvajaju se još dva, S. Her (1985.) s opsežnom ekonomskogeografskom knjigom i Š. Aga s dva rada (1979. i 1980.) koja se dotiču istraživanog područja, o krajoliku i prirodnom biljnom pokrovu gornje Mezopotamije.

\section{PODATCI I METODA RADA}

Poznavanje režima ${ }^{4}$ otjecanja tekućica oslanja se na hidrološka mjerenja, odnosno na registar koji dugoročno prati vodostaje i protoke na određenim mjernim mjestima te na odgovarajuću hidrološku službu za mjerenja i tehničke poslove. Hidrološka služba u Siriji danas djeluje institucionalno u sklopu Ministarstva natapanja Republike Sirije, a do 1972. djelovala je u sklopu Ministarstva poljoprivrede Republike Sirije. Osnovana je još za francuske uprave, 1933. godine.

Za utvrđivanje režima neophodni su podaci s hidroloških postaja. U poriječju Habura najstarije hidrološke postaje osnovane su 1931. godine za francuske uprave. Kako ih je na cijelom toku Habura i pritocima ukupno bilo svega tri (Hassaka i Swar na Haburu i Tal Halaf na vadi Halafu), osnovane su još tri postaje na Haburu 1942. godine (Ras al Ain, Tal Tamer i Manađir). Zbog ukidanja nakon 1953. ostaje svega četiri postaje, pa je pet novih osnovano na prijelazu 1950-ih u 1960-te. Njih tri nalaze se na Haburu, no Šadada i Šeh Hamad su ukinute 1981., a Busayra se nalazi kod ušća, dakle izvan istraživanog područja. Od tada osnovanih postaja je u sklopu istraživanog područja do danas operativna jedino postaja Kamišli na Đakđaku (Svaja na Đakđaku je ukinuta 1989.). Najnovije unaprijeđenje opažačke mreže bilo je osnivanje po jedne postaje na Zarkanu i Đarđapu, no one su osnovane u sklopu planiranja brana 1970-ih., a redovita opažanja provode se tek od 1995. godine. Dakle, s obzirom na veličinu i značenje poriječja Habura, odnosno Gornje Đezire (gornjeg poriječja) razvidno je da hidroloških postaja u funkcionalnom stanju nema dovoljno. Danas ih je operativno svega šest, ali na dvije od njih nizovi su kraći od 10 godina. $\mathrm{Na}$ Haburu, glavnoj tekućici regije danas je funkcionalno ukupno pet hidroloških postaja u Siriji, no u istraživanom području se nalazi njih tri. Na nekim važnim pritocima nema mjerenja (npr. na Radu), a neke su neadekvatno smještene, npr. na Đakđaku je samo jedna i to smještena u gornjem dijelu toka. Dakle, nedostaje povoljno razmještenih mjernih mjesta koja bi ne samo kvantitativno već i kvalitativno unaprijedila poznavanje karakteristika otjecanja. S obzirom da sve do danas nijedna postaja nema automatizirano praćenje vodostaja limnigrafom, već se na svim postajama mjerenje obavlja očitavanjem vodokaznih letvi, potrebna je modernizacija. U tom smislu tek je početkom ovog stoljeća zabilježena određena inicijativa, i na neka mjerna mjesta postavit će se uskoro limnigrafi. 


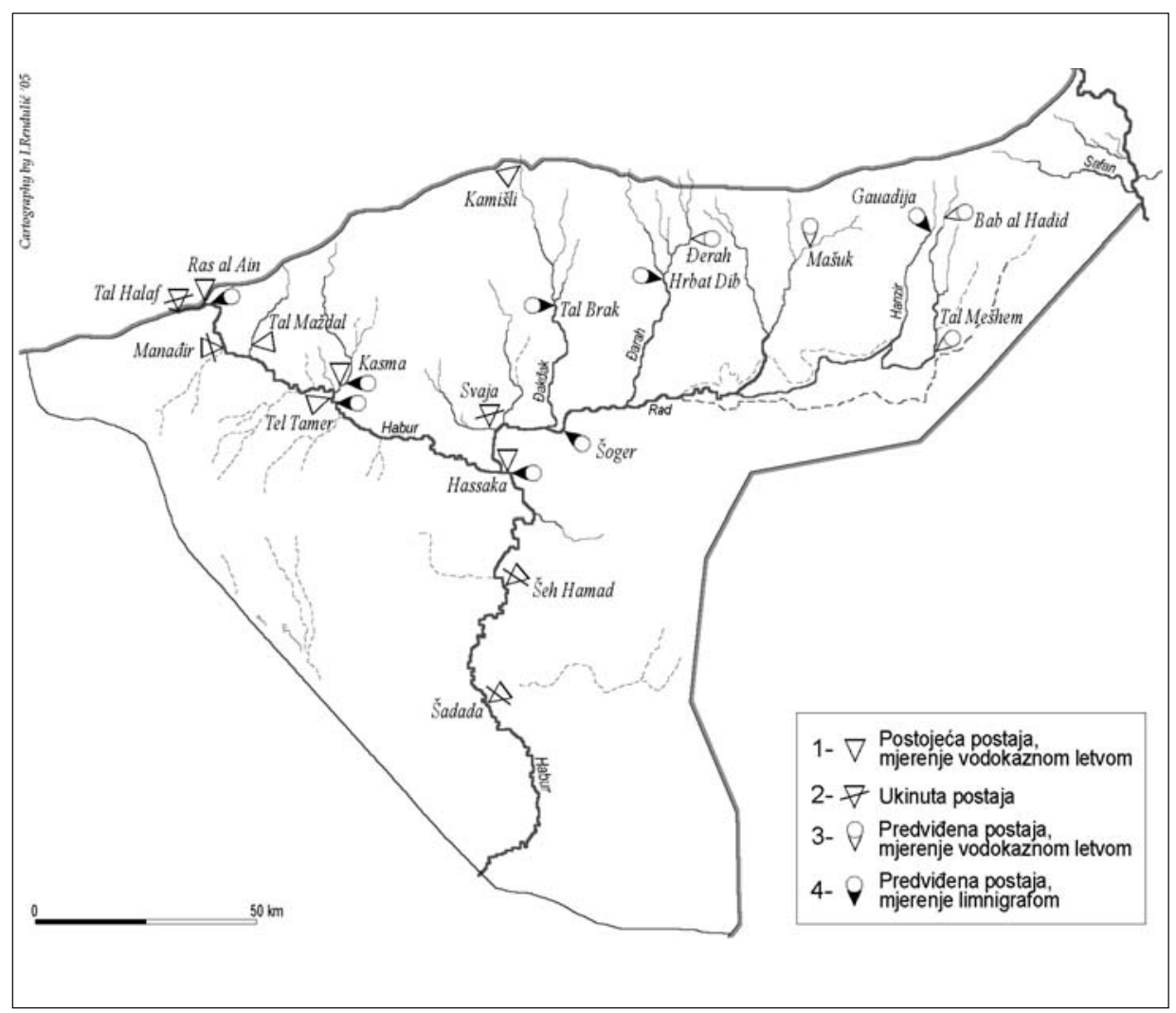

S1. 2. Vodomjerne postaje u gornjem dijelu poriječja Habura, namjesništvo Hassaka, SI Sirija

Fig. 2 Water gauge (hydrologic) stations in the upper part of Khabour catchment area, governorate Hassakah, NE Syria

(1 - Existing water gauge station, manual observation of water level

2 - Abandoned water gauge station

3 - Planned water gauge station, manual observation of water level

4 - Planned water gauge station, automatic observation of water level)

Razmtarajući rad hidroloških postaja, općenito se može reći da su redovita i pouzdana mjerenja na postajama $u$ istraživanom području obavljana na Haburu u Ras al Ainu, Hassaki i Tal Tameru te na Đakđaku u Kamišliju. Od godine 1975. na ovim postajama se mjerenje intenziviralo (ponekad i tri puta dnevno). U ostalim hidrološkim postajama se opaža povremeno neredovito mjerenje, a i pouzdanost podataka razlikuje se od postaje do postaje. U tim postajama su u razdoblju 1958. do 1967. mjerenja bila redovitija, da bi poslije praktički stala, ili bi mjerenja bila obavljana samo u hidrološki oskudnom razdoblju, dakle za malih protoka. To je onemogučilo poznavanje oblikovanja visokih voda, odnosno oblikovanja vodnog vala, kako se navodi u izvještaju Bulgarian Agrocomplex Co. (1976.) koja je istraživala vodne resurse u poriječju Habura. Na postajama na Đarđapu i Zarkanu se tek od 1995. redovito svakodnevno obavlja mjerenje. 
Hrvatski geografski glasnik 67/1 (2005.)

Tab. 1. Srednji mjesečni i godišnji protok $\left(\mathrm{m}^{3} / \mathrm{s}\right)$ na postajama u gornjem dijelu poriječja Habura

Tab. 1 Mean monthly and annual runoff $\left(\mathrm{m}^{3} / \mathrm{s}\right)$ on watergauge stations in upper part of Khabour cathment area

\begin{tabular}{|c|c|c|c|c|c|c|c|c|c|c|c|c|c|}
\hline & I & II & III & IV & $\mathrm{V}$ & VI & VII & VIII & IX & $\mathrm{X}$ & $\mathrm{XI}$ & $\mathrm{XII}$ & Prosj. god. \\
\hline \multicolumn{14}{|c|}{ Ras al Ain / Habur (1943.-2000.) } \\
\hline SQ & 46,8 & 46,5 & 47,0 & 43,8 & 38,2 & 34,5 & 32,8 & 32,4 & 32,9 & 34,8 & 36,0 & 39,3 & 38,7 \\
\hline STD & 23,9 & 16,4 & 19,9 & 21,7 & 19,3 & 11,6 & 12,3 & 12,8 & 12,9 & 10,8 & 11,2 & 11,0 & 13,0 \\
\hline $\mathrm{CV}$ & 0,5 & 0,4 & 0,4 & 0,5 & 0,5 & 0,3 & 0,4 & 0,4 & 0,4 & 0,3 & 0,3 & 0,3 & 0,3 \\
\hline Skew & 2,3 & 2,2 & 1,8 & 1,8 & 1,3 & $-1,4$ & $-1,3$ & $-1,3$ & $-1,3$ & $-1,2$ & $-0,9$ & $-0,2$ & $-0,4$ \\
\hline \multicolumn{14}{|c|}{ Tal Tamer / Habur (1943.-2000.) } \\
\hline SQ & 54,0 & 56,2 & 56,4 & 50,2 & 43,8 & 39,4 & 36,3 & 35,3 & 35,4 & 38,1 & 39,4 & 43,8 & 44,0 \\
\hline STD & 31,6 & 23,6 & 27,3 & 27,1 & 25,3 & 16,1 & 12,9 & 13,3 & 13,0 & 11,3 & 10,7 & 17,8 & 16,0 \\
\hline $\mathrm{CV}$ & 0,6 & 0,4 & 0,5 & 0,5 & 0,6 & 0,4 & 0,4 & 0,4 & 0,4 & 0,3 & 0,3 & 0,4 & 0,4 \\
\hline Skew & 2,5 & 1,0 & 1,2 & 1,8 & 1,9 & 1,7 & $-1,1$ & $-1,3$ & $-1,4$ & $-1,7$ & $-1,4$ & 1,5 & 0,0 \\
\hline \multicolumn{14}{|c|}{ Hassaka / Habur (1943.-2000.) } \\
\hline SQ & 66,1 & 65,5 & 67,4 & 58,6 & 53,0 & 47,2 & 44,4 & 43,9 & 44,0 & 45,6 & 48,2 & 53,2 & 53,1 \\
\hline STD & 37,1 & 29,5 & 33,3 & 35,4 & 30,8 & 24,5 & 21,2 & 20,7 & 20,3 & 17,8 & 17,3 & 22,9 & 23,0 \\
\hline $\mathrm{CV}$ & 0,6 & 0,4 & 0,5 & 0,6 & 0,6 & 0,5 & 0,5 & 0,5 & 0,5 & 0,4 & 0,4 & 0,4 & 0,4 \\
\hline Skew & 1,7 & 0,2 & 0,7 & 0,7 & 0,7 & $-0,1$ & $-1,2$ & $-1,3$ & $-1,3$ & $-1,1$ & $-1,1$ & 0,6 & $-0,7$ \\
\hline \multicolumn{14}{|c|}{ Kamišli / Đakđak (1961.-2000.) } \\
\hline SQ & 7,8 & 8,4 & 7,8 & 8,4 & 5,3 & 2,2 & 0,8 & 0,4 & 0,5 & 3,8 & 5,8 & 7,5 & 4,9 \\
\hline STD & 2,1 & 2,5 & 2,3 & 2,4 & 3,6 & 1,4 & 1,0 & 0,9 & 1,2 & 2,0 & 2,1 & 3,1 & 1,1 \\
\hline $\mathrm{CV}$ & 0,3 & 0,3 & 0,3 & 0,3 & 0,7 & 0,7 & 1,3 & 2,3 & 2,3 & 0,5 & 0,4 & 0,4 & 0,2 \\
\hline Skew & 0,5 & 1,9 & $-1,1$ & $-0,7$ & 0,3 & $-0,3$ & 0,6 & 2,4 & 2,4 & $-0,8$ & $-0,8$ & 2,3 & $-1,0$ \\
\hline \multicolumn{14}{|c|}{ Kasma / Zarkan (1995.-2001.) } \\
\hline SQ & 1,9 & 2,0 & 1,6 & 1,8 & 0,1 & 0,2 & 0,1 & 0,0 & 0,0 & 0,1 & 0,1 & 0,4 & 0,7 \\
\hline STD & 3,0 & 2,3 & 2,0 & 1,6 & 0,1 & 0,5 & 0,2 & 0,0 & 0,0 & 0,1 & 0,2 & 0,4 & 0,6 \\
\hline $\mathrm{CV}$ & 1,6 & 1,1 & 1,2 & 0,9 & 1,3 & 2,6 & 2,6 & - & - & 1,7 & 1,9 & 1,0 & 0,9 \\
\hline Skew & 2,3 & 1,5 & 2,0 & 0,4 & 0,7 & 2,6 & 2,6 & - & - & 1,2 & 1,9 & 0,0 & 0,7 \\
\hline \multicolumn{14}{|c|}{ Đarđap - Tal Maždal / Đarđap (1995.-2001.) } \\
\hline SQ & 5,6 & 5,6 & 4,8 & 4,7 & 0,2 & 0,1 & 0,0 & 0,0 & 0,0 & 0,1 & 0,3 & 0,9 & 1,9 \\
\hline STD & 6,9 & 5,0 & 8,9 & 6,1 & 0,3 & 0,1 & 0,0 & 0,0 & 0,0 & 0,2 & 0,5 & 1,5 & 1,8 \\
\hline $\mathrm{CV}$ & 1,2 & 0,9 & 1,8 & 1,3 & 1,3 & 1,7 & - & - & - & 1,5 & 1,8 & 1,6 & 0,9 \\
\hline Skew & 0,9 & 0,6 & 2,6 & 1,2 & 1,3 & 1,3 & - & - & - & 1,6 & 1,8 & 1,6 & 0,7 \\
\hline
\end{tabular}

Prema podatcima Hidrološke službe Sirije izračunali autori 
Razmatranje režima tekućica u mogućnosti smo provesti na temelju raspolaganja nizovima podataka s hidroloških postaja Ras al Ain (1943. - 2000., N = 58), Tal Tamer (1943. - 2000., $\mathrm{N}=58)$ i Hassaka (1943. - 2000., $\mathrm{N}=58$ ) na Haburu i Kamišli (1961. - 2001., $\mathrm{N}=41$ ) na Đakđaku. Postoje i kraći noviji nizovi (1995. - 2001., $\mathrm{N}=7$ ) na postajama na Đarđapu i Zarkanu.

U svim ovim mjernim postajama autorima je u cijelosti dostupan jedino niz srednjih mjesečnih protoka, dakle ne raspolaže istodobnim nizovima maksimalnih i minimalnih mjesečnih protoka. No kako hidrološka tj. hidrometrijska analiza nije primarna zadaća, ovi podatci dovoljni su za spoznavanje prirodnih režima ${ }^{4}$ tekućica te učinaka suvremene eksploatacije na te režime.

\section{REZULTATI I RASPRAVA}

\section{Hidrografski pregled}

Poriječje Habura ima ukupnu površinu od oko $31800 \mathrm{~km}^{2}$, od čega se $19200 \mathrm{~km}^{2}$ nalazi u Siriji, $11000 \mathrm{~km}^{2}$ u Turskoj, a $1600 \mathrm{~km}^{2}$ u Iraku. Sjeverni dijelovi razvodnice nalaze se u Turskoj, i prostiru se sve do vrhova Torosa, dok se na istoku razvodnica pruža sljemenom Karačoka u Siriji i Sinđara u Iraku. Najveće visine razvodnica doseže na Torosu u Turskoj (1550 m), a ušće se nalazi na 192 m n.m.

Habur ili Nahr al-Khabur je jedan od glavnih pritoka Eufrata. Najdulji izvorišni krak teče s gorja Takirtukur Daği u Turskoj, na tromeđi turskih provincija Mardin, Urfa i Diyarbakir. Ako računamo ukupnu duljinu Habura od izvora u Turskoj do ušća u Siriji, tada ona iznosi oko $460 \mathrm{~km}$ (prema podacima Ministarstva natapanja). U literaturi se spominju i duljine 402, 405, 440 i $442 \mathrm{~km}$. Međutim, Habur se u Siriji često smatra unutrašnjom sirijskom rijekom, iako su rubni dijelovi poriječja i izvan granica Sirije. Ovaj stav ima svoje opravdanje u činjenici da je hidrološki najbogatiji izvorišni krak kao i glavni izvor rijeke Habur u Siriji, kod grada Ras al Ain. U turskom dijelu poriječja sjevernije od Ras al Aina nema toliko jakih izvora, pa su dugi izvorišni krakovi Habura i njegovih pritoka sezonski. Od Ras al Aina Habur otječe općenito na jugoistok do grada Hassake i zatim općenito na jug, te se ulijeva u Eufrat kod gradića Basira jugoistočno od Der Az Zora.

Veliku većinu tokova u gornjem poriječju Habura čine povremene tekućice, nevezane za razinu temeljnice, aktivne samo za jakih kiša (vadiji). Tijekom godine vadiji su suhi, osim u razdoblju poplava, kad voda teče većim ili manjim dijelom toka, a duljina otjecanja u izravnoj je vezi s trajanjem i intenzitetom padalina. $U$ istraživanom području može se izdvojiti tri područja s većom koncentracijom vadija, vezano uz gorska uzvišenja Karačoka, Sinđara i Abd al Aziza. Vadiji s Karačoka i Sinđara razmjerno su dugi i usmjereni u potolinsko područje doline Rada.

U vlažnijim, sjevernijim dijelovima istraživanog područja uobičajene su sezonske tekućice, koje tijekom hladnog, kišnog dijela godine imaju stalan protok vode, dok u toplom dijelu godine presušuju uobičajeno na 4 do 5 mjeseca. Najvažnije sezonske tekućice koje se ulijevaju u Rad su: Remelan, Remela, Hnezir, Đarah i Bređ. One se u Rad spuštaju s planinskog uzvišenja Karačok istočno od doline Đakđaka. Zapadno i sjeverno od Đakđaka, teku sezonske tekućice kao glavni desni pritoci Đakđaka. To su Sbaat, 
Tel Arus i Aueđ koji, spuštajući se sa Torosa, svi skupljaju vodu niza manjih, uglavnom povremenih tekućica. U gornjem dijelu toka Habur prima dvije važne sezonske tekućice, lijeve pritoke Đarđab i Zarkan (Zargan). Iznimno je važno istaknuti da su obje ove tekućice do 1995. godine bile stalne tekućice. Od početka 1990-ih opaža se povremeno presušivanje u duljem razdoblju, odnosno od 1995. počinju presušivati na nekoliko mjeseci, da bi danas bile sezonske tekućice suhe 3 do 4 mjeseca u godini. Na žalost, sustavno mjerenje na obje tekućice (letvom) počinje tek 1995., nakon ove pojave. Uzrok ove pojave treba tražiti ponajprije u sniženju razine podzemne vode zbog prekomjernog crpljenja vode (bušeni bunari, dizel-crpke) za potrebe natapanja (Bahnan, 2003.). U gornjem toku Habura kao desni pritoci još su sezonske tekućice Đafar, Magluđa i Sus koji izviru iz stalnih izvora podno sjeverne padine Abd al Aziza. Iako su izvori stalni, te su tekućice također suhe 2 do 3 mjeseca tijekom sušne sezone.

U istraživanom području osim Habura stalnog su karaktera i njegov glavni pritok Đakđak (Jaghjagh) sa svojim pritokom Radom (Radd). Na 28 km zračne udaljenosti sjeverno od Kamišlija nalazi se glavni izvor Đakđaka Karaso (Crnavoda) na hidrološki glavnom kraku, no najdulji izvorišni krak je i dulji. Rijeka se u Turskoj naziva Korvazbonizra. Turska je na Đakđaku nedaleko granice podigla zaporna vrata i nadzire protok. Iako je prosječno godišnje bogatija vodom rijeka Rad smatra se pritokom Đakđaka. Rad izvire kao vadi Bab el Hadid na Karačoku i spušta se općenito na jug. Od mjesta Al Taš mijenja ime u Rad i otječe općenito na zapad do sutoka s Đakđakom u duljini od $86 \mathrm{~km}$. Poriječje mu je asimetrično, te dulje i vodom bogatije tekućice prima sa sjevera. Izohipsa od 350 m približno se poklapa s granicama povremeno močvarnog dijela doline Rada. To je potolinsko područje dugo oko $60 \mathrm{~km}$, široko 20 -ak km u svom istočnom dijelu, a 15 -ak km u središnjem i oko $5 \mathrm{~km}$ na zapadnom dijelu u kojem su korita tekućica nestabilna (zbog prevladavajuće akumulacije) pa rijeke formiraju čitav splet rukavaca i starih korita. Mnogi od pritoka Rada su u svojim donjim tokovima, zbog visokih temperatura tijekom godine, odnosno jake evaporacije, zapravo periodični tokovi. Do kraja 1980-ih ovo je područje bilo stalna močvara, no nakon intenzivnijeg poljoprivrednog iskorištavanja voda sjevernih pritoka (izgradnja brana u poriječjima Bab el Hadida, Hanzira i Đaraha) močvara je postala sezonska i došlo je do intenzivnog zaslanjivanja. Poznato je da se nekad mogla voda močvare Rad koristiti za piće, a danas vodu (od 3 do 5 g soli u litri) koriste samo za napajanje ovaca (Bahnan, 2003.).

\section{Godišnji protok}

Otjecanje rijeke Habur prati se sustavno u istraživanom području od 1943. godine na tri opažačka mjesta. To su Ras el Ain, koje se, s obzirom na značenje ove skupine izvora, može shvatiti gotovo kao izvorište Habura (o čemu je već bilo riječi u hidrografskom pregledu), zatim Tal Tamer i Hassaka, najnizvodnija postaja na Haburu u Gornjoj Đeziri.

Razmatranje režima na najvažnijoj tekućici regije, koja odvodnjava gotovo cijelo područje Đezire, započinjemo praćenjem prosječnog godišnjeg otjecanja. U svezi s tim najprije se treba osvrnuti na dosadašnja istraživanja i spoznaje po tom pitanju. Kod rijeke Habur nalazi se u literaturi, odnosno dostupnim studijama dosta podataka koje se tiču godišnjeg otjecanja u Ras al Ainu, Tal Tameru i Hassaki, pojedinačno ili zajedno. Ponekad 
se objavljuju različiti podaci o srednjem godišnjem protoku, ovisno o tome objavljuje li ga Ministarstvo poljoprivrede ili Ministarstvo natapanja. Ministarstvo poljoprivrede ponekad objavljuje vlastite procjene koje su više od službenih hidroloških podataka pri Ministarstvu natapanja, iz razloga da bi dobilo dozvolu za uzgoj pamuka u regiji. Time se međutim dugoročno ne čini usluga poljoprivrednicima i općenito stanovništvu regije (Bahnan, 2003.).

Studija Bulgarian Agrocomplex Co. (1976.) u kojoj se razmatraju i varijacije srednjeg protoka Habura u razdoblju 1942. - 1970. pokazala je pak da se srednji protok Habura povećava od $50 \mathrm{~m}^{3} / \mathrm{s}$ (ili $1577 \mathrm{mil} \mathrm{m}^{3}$ godišnje) kod Ras al Aina do $62 \mathrm{~m}^{3} / \mathrm{s}$ (1955 mil. $\mathrm{m}^{3}$ godišnje) kod Swara (40-ak km od ušća). U toj studiji ističe se da je proticaj u sušno doba u razmatranom razdoblju, dakle kad se rijeka prihranjuje samo na račun izvora, bez površinskih dotoka, iznosio $47 \mathrm{~m}^{3} / \mathrm{s}$ (1482 mil. $\mathrm{m}^{3}$ godišnje) kod Tal Tamera, te se ovaj iznos smatra konstantnim, odnosno iznosom minimalnog ili baznog protoka Habura, kada se rijeka opskrbljuje uglavnom iz skupine izvora kod Ras al Aina, iz eocenskih vapnenaca (drugi vodonosni kompleks) izdašnosti 40-ak m³ $/$ s. Interni izvještaj Ministarstva poljoprivrede Sirije iz 1986. oslonio se na analizu niza iz hidroloških godina u razdoblju 1942. do 1976. godine, te je ustvrdilo da je godišnja raspoloživa količina vode u Haburu za prosječno kišnu godinu kod Ras al Aina 1396,6 mil. m³ , za sušnu godinu 1261,4 mil. $\mathrm{m}^{3}$ te za jako sušnu godinu 1261,4 mil. m³ , a da u prosječno kišnoj godini kod Swara iznosi 1442,2 mil $\mathrm{m}^{3}$ godišnje. Primjetno je smanjenje izraženih protoka u odnosu na prethodno spomenutu studiju. Najnoviji je interni izvještaj Ministarstva poljoprivrede Sirije iz 1997. godine u kojem se na temelju analize niza iz 12 novijih hidroloških godina od 1984. do 1996. utvrđuje da je srednji protok kod Ras al Aina varirao između 1063 i 587 mil. $\mathrm{m}^{3}$ godišnje, što je jasno i znatno smanjenje u odnosu na razmatranja iz ranijih razdoblja.

Razmotrimo li nizove iz kalendarskih godina započevši s 1943. pa do 2000. kojima raspolažemo za postaje Ras al Ain, Tal Tamer i Hassaka i promotrimo li samo podatke za prosječan i ukupan godišnji protok možemo potvrditi da postoji velika razlika na početku i na kraju niza. Sastavi li se prikaz prosječnog godišnjeg protoka u razdoblju 1943. - 2000. za sve tri razmatrane postaje, postaje bjelodano jasno o kakvim se promjenama radi (sl. 3). Te se razlike nikako ne mogu pripisati promjenama u kakvoći opažanja, što neizravno možemo zaključiti iz razmjerno uravnoteženih prosječnih godišnjih otjecanja u nizu za sve tri postaje do početka 1980-ih godina.

Dakle početkom 1980-ih počinje ono što možemo opisati prvo opadanjem, a u 1990im upravo dramatičnim opadanjem prosječnih godišnjih protoka na sve tri postaje. U posljednjem razdoblju čak je došlo do neuobičajene situacije u kojoj postaja Hassaka bilježi niže prosječne godišnje protoke od uzvodnijih postaja Ras al Ain i Tal Tamer. Naravno da ne može biti govora o prirodnom procesu, već se ovdje radi o intenzivnom iskorištavanju vode. Prvenstveno se to odnosi na naseljavanje i poljoprivredno iskorištavanje doline Habura koje je intenzivirano upravo s početkom 1980-ih. Broj poljoprivrednih bunara posebno je brzo rasao od 1985. godine (Bahnan, 2003.). Voda se crpi iz podzemlja, ali i izravno iz rijeke Habur tada nabavljenim diezel motornim crpkama, koje posve mijenjaju tradicionalne načine navodnjavanja i vodoopskrbe. Crpljenje vode intenzivno je u području oko glavnog grada namjesništva Hassake, a osim toga znatno je smanjen dotok glavnim pritokom Đakđakom, budući da su naravno i uz Đakđak i njegove pritoke od 1980-ih 
na djelu intenzivni procesi u naseljavanju i poljodjelskoj obradi. Rečeno može objasniti razmjerno naglije opadanje prosječnih protoka na postaji Hassaka budući je ona smještena na Haburu nakon ušća Đakđaka.

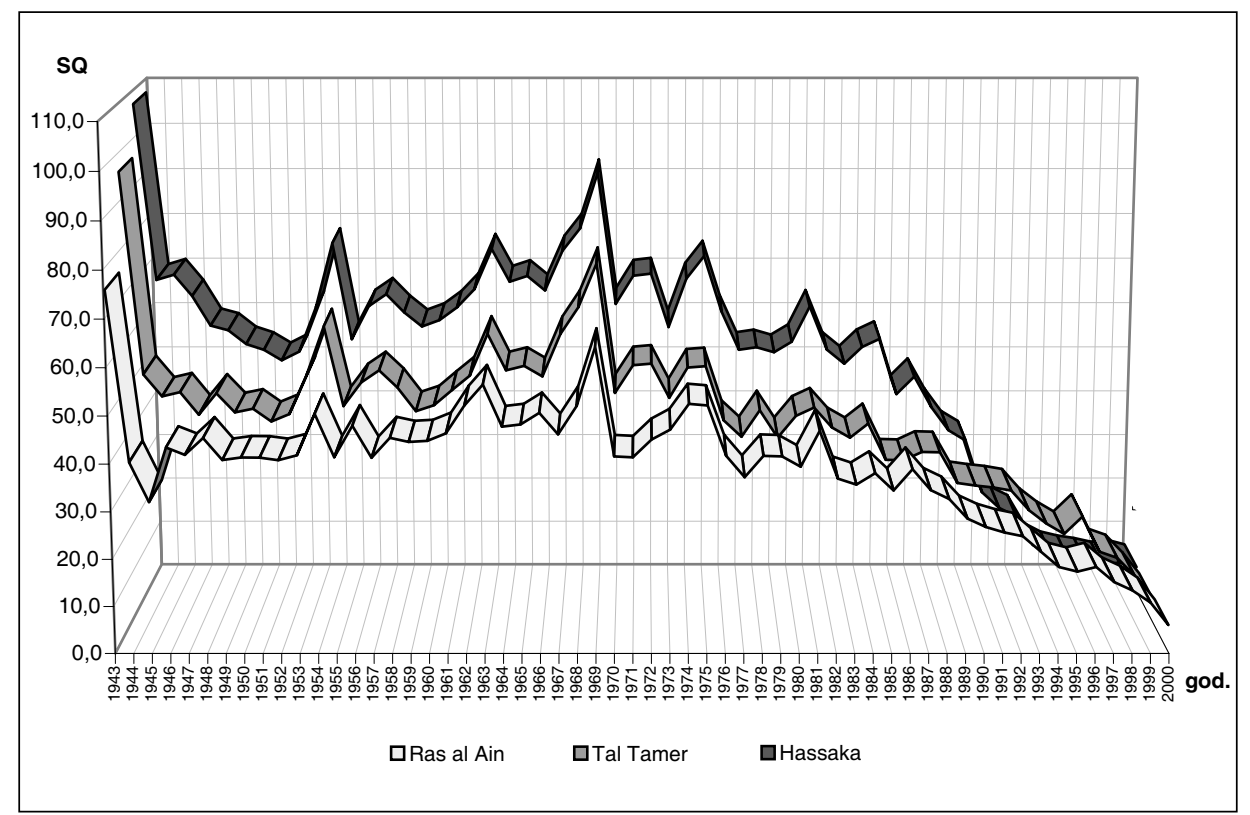

S1. 3. Prosječni godišnji protoci $\left(\mathrm{m}^{3} / \mathrm{s}\right)$ na Haburu u razdoblju 1943.-2000.

Fig. 3 Mean annual runoff $\left(\mathrm{m}^{3} / \mathrm{s}\right)$ on Khabour in period 1943-2000

Područje oko Tal Tamera najmanje je izloženo crpljenju vode iz podzemlja (do 1951. uopće nije bilo nijednog bunara), pa je postaja Tal Tamer često uzimana kao referentna za praćenje prirodnog ritma otjecanja Habura. Međutim, u zadnjih dvadesetak godina najprije su intenzivirana crpljenja i kod Tal Tamera, a najvažnije je da je 1996. godine dovršenjem kanala Tal Magas znatan dio vode uskraćen za protok kod Tal Tamera. Naime, kanal odvodi vodu Habura od Tal Magasa (nizvodno oko $11 \mathrm{~km}$ od Ras al Aina) do umjetnih jezera brana Zapadna Hassaka i nedaleke Istočne Hassake. Voda ovih umjetnih jezera koristi se za natapanje i vodoopskrbu stanovništva grada Hassaka. Iz ovih umjetnih jezera višak vode se vraća u Habur prije postaje Hassaka. Na taj način su izmijenjeni prirodni protoci nakon 1996. kod Tal Tamera, ali i kod Hassake (budući je dio još vode intenzivnije iskorišten, a dio isparava s površine jezera).

Važno je istaknuti da je crpljenje vode u novijem razdoblju pojačano i sa i u okolici izvorišta Ras al Ain, glavnog izvora rijeke Habur (Bahnan, 2003.). 


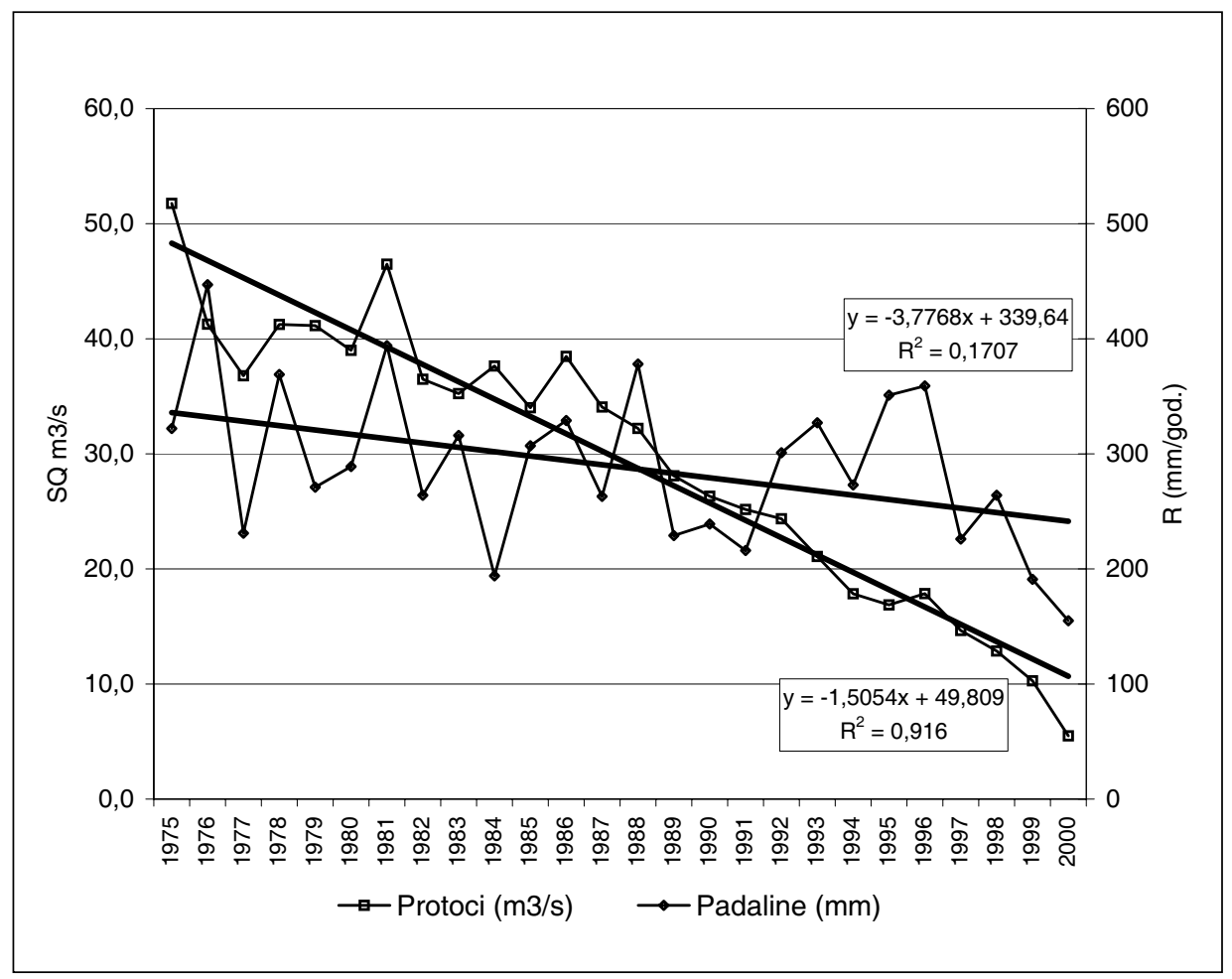

S1. 4. Usporedba godišnjih padalina (meteorološka postaja Ras al Ain) i srednjih godišnjih protoka (vodomjerna postaja Ras al Ain/Habur) u razdoblju 1975.-2000. god.

Fig. 4 Comparison of annual precipitation (metheorological station Ras al Ain) and mean annual runoff (watergauge station Ras al Ain / Khabour) in period 1975-2000

Na sl. 4 prikazana je usporedba kretanja godišnjih padalina na meteorološkoj postaji Ras al Ain u razdoblju 1975. - 2000. i kretanja srednjih godišnjih protoka na hidrološkoj postaji Ras al Ain. Kretanje protoka pokazuje izrazit trend opadanja, kojeg dobro $\left(\mathrm{R}^{2}=\right.$ $0,916)$ opisuje regresijska linija $y=-1,5054 x+49,809$ što drugim riječima znači da $u$ posljednjoj četvrtini 20 . stoljeća postoji prosječno smanjenje protoka od čak $1,5 \mathrm{~m}^{3} / \mathrm{s}$ svake godine ili ukupno čak oko $39 \mathrm{~m}^{3} / \mathrm{s}$, ili s oko 50 -ak na samo 10 -ak m³ $/ \mathrm{s}$. Trend bi bio još oštriji ako bi ga izračunali za razdoblje od sredine 1980-ih godina. S druge strane kretanje godišnjih količina padalina u postaji Ras al Ain u razdoblju 1975. - 2000. pokazuje da postoji određeno smanjenje godišnje količine padalina, međutim kada se izračuna trend linija regresije slabo opisuje $\left(\mathrm{R}^{2}=0.1707\right)$ pad od oko $3,8 \mathrm{~mm}$ godišnje. To znači u cijelom razdoblju pad od oko $98 \mathrm{~mm}$. To nije beznačajan iznos, međutim statistički je opis slab, a osim toga trend je odvučen smanjenjem padalina od 1996. godine kojeg bilježe i ostale meteorološke postaje u regiji (Bahnan, 2003.).

Iznimno zabrinjava pad protoka na postaji Ras al Ain na Haburu, budući da je nešto uzvodnije glavno izvorište napajanja Habura vodom u Siriji. Ovakvo smanjenje dotoka 
Tab 2. Prosječni i izvedeni ukupni protoci na Haburu i njegovim pritocima 1961.-1980. i 1981.-2000. Tab. 2 Mean and total runoff on Khabour and it's tributaries for periods 1961-1980 and 1981-2000

\begin{tabular}{|c|c|c|c|c|c|c|c|c|c|c|c|c|c|}
\hline & I. & II. & III. & IV. & V. & VI. & VII. & VIII. & IX. & $\mathrm{X}$. & XI. & XII. & god. \\
\hline \multicolumn{14}{|c|}{ Ras al Ain 1961. - 1980.} \\
\hline $\mathrm{SQ}(\mathrm{m} 3 / \mathrm{s})$ & 51,6 & 52,8 & 55,7 & 52,2 & 48,3 & 42,0 & 41,2 & 41,1 & 41,7 & 42,8 & 45,2 & 47,8 & 46,9 \\
\hline $\begin{array}{l}=\text { ukupni Q } \\
\left(\text { mil. } \mathrm{m}^{3}\right)\end{array}$ & 138,2 & 127,8 & 149,3 & 135,3 & 129,4 & 108,7 & 110,2 & 110,0 & 108,2 & 114,7 & 117,1 & 128,1 & 1476,9 \\
\hline \multicolumn{14}{|c|}{ Ras al Ain 1981. - 2000.} \\
\hline $\mathrm{SQ}(\mathrm{m} 3 / \mathrm{s})$ & 31,1 & 35,5 & 33,0 & 27,5 & 22,5 & 23,2 & 19,9 & 18,8 & 19,7 & 23,8 & 25,0 & 29,9 & 25,8 \\
\hline $\begin{array}{l}=\text { ukupni Q } \\
\left(\mathrm{mil} . \mathrm{m}^{3}\right)\end{array}$ & 83,3 & 86,0 & 88,5 & 71,2 & 60,2 & 60,0 & 53,4 & 50,5 & 50,9 & 63,8 & 64,7 & 80,2 & 812,8 \\
\hline \multicolumn{14}{|c|}{ Tal Tamer 1961. - 1980.} \\
\hline $\mathrm{SQ}(\mathrm{m} 3 / \mathrm{s})$ & 61,1 & 67,7 & 67,7 & 60,0 & 55,7 & 46,9 & 44,0 & 43,7 & 43,5 & 46,0 & 47,0 & 55,0 & 53,2 \\
\hline $\begin{array}{l}=\text { ukupni Q } \\
\left(\mathrm{mil} . \mathrm{m}^{3}\right)\end{array}$ & 163,7 & 163,8 & 181,3 & 155,5 & 149,3 & 121,7 & 117,8 & 117,0 & 112,8 & 123,2 & 121,8 & 147,3 & 1675,0 \\
\hline \multicolumn{14}{|c|}{ Tal Tamer 1981. - 2000.} \\
\hline $\mathrm{SQ}(\mathrm{m} 3 / \mathrm{s})$ & 34,0 & 37,2 & 36,7 & 30,2 & 23,1 & 25,1 & 22,0 & 20,2 & 21,1 & 26,6 & 28,2 & 30,6 & 27,9 \\
\hline $\begin{array}{l}=\text { ukupni Q } \\
\left(\mathrm{mil} . \mathrm{m}^{3}\right)\end{array}$ & 90,9 & 89,9 & 98,2 & 78,4 & 61,8 & 65,1 & 58,9 & 54,1 & 54,7 & 71,3 & 73,0 & 82,0 & 878,4 \\
\hline \multicolumn{14}{|c|}{ Hassaka 1961. - 1980.} \\
\hline $\mathrm{SQ}(\mathrm{m} 3 / \mathrm{s})$ & 79,5 & 83,5 & 84,4 & 75,5 & 69,7 & 60,0 & 56,6 & 56,6 & 55,9 & 57,0 & 59,7 & 68,4 & 67,2 \\
\hline $\begin{array}{l}=\text { ukupni Q } \\
\left(\mathrm{mil}^{3} \mathrm{~m}^{3}\right)\end{array}$ & 212,9 & 202,0 & 226,2 & 195,8 & 186,6 & 155,6 & 151,5 & 151,5 & 144,9 & 152,8 & 154,6 & 183,2 & 2117,4 \\
\hline \multicolumn{14}{|c|}{ Hassaka 1981. - 2000.} \\
\hline $\mathrm{SQ}(\mathrm{m} 3 / \mathrm{s})$ & 38,4 & 39,0 & 40,2 & 27,8 & 26,1 & 24,0 & 22,3 & 22,1 & 22,7 & 26,2 & 29,6 & 33,8 & 29,3 \\
\hline $\begin{array}{l}=\text { ukupni Q } \\
\left.\left(\mathrm{mil}^{3}\right)^{3}\right)\end{array}$ & 102,8 & 94,4 & 107,6 & 71,9 & 69,9 & 62,3 & 59,6 & 59,2 & 58,8 & 70,3 & 76,6 & 90,4 & 923,8 \\
\hline \multicolumn{14}{|c|}{ Kamišli/Đakđak 1961. - 1980.} \\
\hline $\mathrm{SQ}(\mathrm{m} 3 / \mathrm{s})$ & 8,4 & 8,7 & 8,6 & 8,4 & 5,0 & 2,1 & 1,2 & 0,8 & 1,1 & 4,5 & 6,7 & 7,8 & 5,3 \\
\hline $\begin{array}{l}=\text { ukupni Q } \\
\left(\mathrm{mil} . \mathrm{m}^{3}\right)\end{array}$ & 22,6 & 21,1 & 23,0 & 21,7 & 13,4 & 5,4 & 3,2 & 2,1 & 2,8 & 11,9 & 17,5 & 21,0 & 165,6 \\
\hline \multicolumn{14}{|c|}{ Kamišli/Đakđak 1981. - 2000.} \\
\hline $\mathrm{SQ}(\mathrm{m} 3 / \mathrm{s})$ & 7,2 & 8,1 & 7,0 & 8,4 & 5,7 & 2,3 & 0,5 & 0,0 & 0,0 & 3,2 & 4,8 & 7,1 & 4,5 \\
\hline $\begin{array}{l}=\text { ukupni Q } \\
\left(\mathrm{mil} . \mathrm{m}^{3}\right)\end{array}$ & 19,2 & 19,5 & 18,7 & 21,6 & 15,2 & 5,9 & 1,2 & 0,0 & 0,0 & 8,4 & 12,3 & 19,0 & 141,1 \\
\hline \multicolumn{14}{|c|}{ Kasma/Zarkan 1995. - 2001.} \\
\hline $\mathrm{SQ}(\mathrm{m} 3 / \mathrm{s})$ & 1,9 & 2,0 & 1,6 & 1,8 & 0,1 & 0,2 & 0,1 & 0,0 & 0,0 & 0,1 & 0,1 & 0,4 & 0,7 \\
\hline $\begin{array}{l}=\text { ukupni Q } \\
\left(\mathrm{mil} . \mathrm{m}^{3}\right)\end{array}$ & 5,1 & 4,9 & 4,4 & 4,7 & 0,2 & 0,4 & 0,2 & 0,0 & 0,0 & 0,1 & 0,3 & 1,2 & 21,5 \\
\hline \multicolumn{14}{|c|}{ Tal Maždal/Đarđap 1995. - 2001.} \\
\hline $\mathrm{SQ}(\mathrm{m} 3 / \mathrm{s})$ & 5,6 & 5,6 & 4,8 & 4,7 & 0,2 & 0,1 & 0,0 & 0,0 & 0,0 & 0,1 & 0,3 & 0,9 & 1,9 \\
\hline $\begin{array}{l}=\text { ukupni Q } \\
\left(\mathrm{mil} . \mathrm{m}^{3}\right)\end{array}$ & 15,1 & 13,6 & 12,9 & 12,2 & 0,6 & 0,2 & 0,0 & 0,0 & 0,0 & 0,3 & 0,7 & 2,4 & 58,1 \\
\hline
\end{tabular}

Prema podatcima Hidrološke službe Sirije izračunali autori 
vode iz izvorišta Ras al Ain utjecat će pogubno na otjecanje Habura. Može se naslutiti da je pad protoka određenim dijelom uvjetovan padom količine padalina u okolici, no u kolikoj mjeri za sada se ne može točno odrediti. Ne raspolažemo podatcima s meteoroloških postaja u Turskoj, u području koje opskrbljuje drugi vodonosni kompleks izvorišta Ras al Ain, no pretpostavljamo da one ne bilježe značajniji pad godišnjih padalina od meteorološke postaje Ras al Aina. Možemo na temelju iznesenih podataka za sada pretpostaviti da na pad protoka Habura kod Ras al Aina manjim dijelom utječe određeno dugoročno smanjenje padalina, a većim dijelom crpljenje vode, kako u Siriji, tako i u Turskoj (iz podzemlja), koje je takvog intenziteta da je moglo smanjiti i bazni protok.

Usporedba prosječnih i prosječnih ukupnih godišnjih protoka iz razdoblja dvaju uzastopnih dvadesetogodišnjih razdoblja 1961. - 1980. i 1981. - 2000. (tab 2) dodatno potvrđuje o kakvim se razlikama radi. Usporedba dvaju uzastopnih dvadestogodišnjih razdoblja 1961. - 1980. i 1981. - 2000. je odabrana kao primjerena jer su to dovoljno dugi nizovi na temelju kojih se mogu izvesti zaključci o režimima, ali na kojima će se jasno istaknuti razlike prije i poslije intenzificiranja eksploatacije vodnih resursa ponajprije zbog znatnog naseljavanja i pojačane agrarne proizvodnje u regiji. To se posebice odnosi na poticani uzgoj pamuka u zadnjem razdoblju koji zahtijeva znatno natapanje. U zadnjem dvadesetogodišnjem razdoblju u odnosu na prethodno došlo je praktički do prepolavljanja prosječnog godišnjeg protoka Habura. U slučaju Hassake SQ 1981.-2000. je svega 44\% onog iz prethodnog dvadesetogodišnjeg razdoblja. Prema srednjim mjesečnim protocima možemo (množenjem s brojem sekundi u svakom pojedinom mjesecu) doći do odgovarajućih ukupnih mjesečnih protoka, koje kada zbrojimo dobijemo ukupni godišnji protok koji odgovara srednjacima iz odgovarajućeg razdoblja. Na taj način procijenjena je srednja godišnja količina vode što protječe na pojedinim postajama u milijunima $\mathrm{m}^{3}$. Lako se može zaključiti da se izvedeni podatci dobro slažu s prethodno iznesenim podatcima iz izvještaja Ministarstva poljoprivrede koji govore o smanjenju ukupnog protoka kod Ras al Aina. Prema našim proračunima on se smanjio s 1476,9 mil. m³ (razdoblje 1961. - 1980.) na 812,8 mil. $\mathrm{m}^{3}$ (razdoblje 1981. - 2000.) u prosječnoj godini. Na najnizvodnijoj razmatranoj postaji Hassaka raspolaže se sa svega 923,8 mil. $\mathrm{m}^{3}$ u prosječnoj godini u zadnjih 20 godina 20. stoljeća.

Smanjenje protoka na Đakđaku nije znatno na prvi pogled, međutim s obzirom da se Kamišli nalazi u gornjem toku, zapravo nedaleko mjesta gdje Đakđak postaje stalnom tekućicom, ono je veliko. Ipak, o režimu Đakđaka teško je pisati s obzirom da potpuni nadzor nad protokom ima Turska, koja je nedaleko granice sa Sirijom podigla zaporna vrata na rijeci. Nizvodno od Kamišlija tek počinje njegova intenzivno obrađena dolina Đakđaka, te prima svoj glavni pritok Rad. Za sam Rad na žalost nema podataka, no već je istaknuto da je do kraja 1980-ih stalna močvara Rada znatno smanjena i postala sezonska, te je jasno da se protok Rada bitno smanjio. 


\section{ZAKLJUČAK}

Za istraživano područje može se reči da je voda odlučujuće utjecala na dosadašnji društveno-gospodarski razvoj te je njezino plansko iskorištavanje preduvijet daljnjeg održivog razvitka. Teorijske postavke održivog razvitka daju čvrstu osnovu ovakvom razmatranju odnosa. O raspoloživim količinama ovisi demografski razvoj i poljoprivreda kraja. To je tim važnije što je Gornja Đezira glavno sirijsko područje poljoprivredne, posebice poljodjelske proizvodnje.

Iz iznesenih podataka zaključuje se da postoji primjetno smanjenje godišnjih protoka na Haburu, počevši od 1970-ih, što je u određenoj mjeri povezano s novijom imigracijom i intenzifikacijom poljodjelske proizvodnje u zavali Gornje Đezire. U zadnjem dvadesetogodišnjem razdoblju u odnosu na prethodno došlo je praktički do prepolavljanja prosječnog godišnjeg protoka Habura. Neke tekućice u poriječju Habura koje su ranije bile stalne sada su povremene.

Životno je važno pitanje vode u podzemlju drugog vodonosnog kompleksa (srednjoeocenski vapnenac) budući da voda tog vodonosnika praktički hrani preko Ras al Aina rijeku Habur, rijeku koja čini oslonac privrednog života namjesništva Hassaka. Voda drugog vodonosnog kompleksa zajednička je s Turskom, odnosno velikim dijelom dolazi iz Turske. S obzirom da je taj vodonosnik iznimno propusan i osjetljiv na crpljenje, važno je da se u najkraćem roku utvrdi pravičan i adekvatan sporazum između Sirije i Turske koji će regulirati korištenje površinskih i podzemnih vodnih resursa.

Pretjerano i dobrim dijelom neplansko iskorištavanje vode iz tekućica i podzemlja moglo bi dovesti do poteškoća kakve su već poznate u nekim drugim dijelovima svijeta, rezultirajući u konačnici trajnim gubitkom akvifera odnosno rezervi vode u podzemlju, što bi imalo goleme posljedice ne samo za regiju, već i cijelu Siriju.

\section{POZIVNE BILJEŠKE}

1. Đezira, u doslovnom prijevodu s arapskog znači otok. Taj naziv ima povijesne korijene i tradicionalno se odnosi na mnogo veći prostor, na područje gornje Mezopotamije, odnosno "otok" između gornjih dijelova tokova Tigrisa i Eufrata, što se na jugoistok stere do uključivo istoimene pustinje (pustinja Đezira) u Iraku, na prijelazu iz Gornje u Donju Mezopotamiju. U Siriji je do polovice 20. st. bilo uobičajeno sav prostor sjeveroistočno od Eufrata (arap.: Al Furat, u značenju čista voda) nazivati Đezira, no danas je taj pojam postao istovjetan za današnje namjesništvo Hassaka.

2. Sirijska Arapska Republika ima površinu od $185180 \mathrm{~km}^{2} \mathrm{~s}$ ukupno 13782119 stanovnika (popis 1994.). Država je sastavljena od 14 namjesništava (arap.: muhafazah), a svako namjesništvo je podijeljeno na nekoliko mantika (u značenju pokrajina), ovisno o veličini samog namjesništva. Ukupno je u Siriji 59 mantika, a na nižoj razini administrativno-teritorijalne podjele mantike su podijeljene na nahije, kojih je u Siriji ukupno 291. Svaku nahiju čini određeni broj naselja, koji znatno varira ovisno o obliku naseljenosti pojedinog kraja. Zakonski nahija mora imati najmanje 30000 stanovnika. Prema popisu iz 1994. godine ukupno je u Siriji 14046 naselja.

3. Poljoprivredno značenje istraživanog područja ogleda se primjerice u činjenici da namjesništvo Hassaka zauzima 12,6\% površine Sirije, a daje godišnje (prema podacima 2000. godine; Statistički godišnjak Sirije) 
Danijel Orešić, Georgos Bahnan - Promjene režima otjecanja tekućica u gornjem dijelu poriječja Habura u sjeveroistočnoj Siriji u drugoj polovici XX. st. - dio I: godišnji protoci

oko 428800 t pamuka (u razdoblju 1984. - 2000. varira od 28 do $50 \%$ ukupne sirijske proizvodnje), oko 1,75 mil. t pšenice (u razdoblju 1984. - 2000. varira od 42 - $55 \%$ ukupne sirijske proizvodnje) i 55000 t leće (u razdoblju 1984. - 2000. varira od 43 - 85 \% sirijske proizvodnje s tim da je 1999. iznosila $100 \%$ ). Čak 1/3 poljoprivredno aktivnog stanovništva nalazi se u namjesništvu Hassaka.

4. Pod pojmom režim otjecanja tekućice ili samo režim tekućice postoji u literaturi više definicija. M Pardé je zastupao mišljenje da je riječni režim "kompleks pojava koje utječu na opskrbu tekućica i promjenu njihovih stanja”. Režim tekućice obuhvaća poznavanje načina prihrane tekućice vodom, godišnjih protoka te raspodjele karakterističnih protoka (ako ih nema onda vodostaja) u koritu rijeke tijekom hidrološke ili kalendarske godine (Riđanović, 1993.). Godišnji hod protoka tema je očekivanog drugog dijela članka.

\section{LITERATURA}

Abd al Salam, A. 1990.: Opća geografija Sirije. Sveučilišna naklada, svezak 4 (ukupno 4 sveska), na arapskom, Damask.

Aga, Š. 1979.: Čovjek i geografska prirodna sredina u gornjoj Mezopotamiji. Geografski glasnik, na arapskom, Damask.

Aga, Š. 1980.: Prirodni biljni pokrov gornje Mezopotamije. Geografski glasnik, na arapskom, Damask.

Bahnan, G. 1991.: Disperzna naseljenost kao problem uređenja regije Malikiya u Siriji. Magistarski rad, Geografski odsjek PMF-a, Zagreb.

Bahnan, G. 2003.: Hidrogeografske osnove razvoja naseljenosti kotara hassaka u sjeveroistočnoj Siriji. Doktorska disertacija. Geografski odsjek PMF-a, Zagreb.

Boghossian, M. 1952.: Srijska Đezira. Doktorska disertacija. Sveučilište Sv. Josip u Bejrutu, Geografski odsjek, na arapskom, Bejrut. Djelom objavljeno: Bohhossian, M. (1956.): Une région particuliere: La Djezirah. Annales de la Faculte de Droit de l'Universite Saint Joseph, vol. 1, Bejrut.

Burdon, D. J. 1954.: Report to the Government of the United Arab Republic on Ground-water Developement and Conservation in Syria. FAO ETAP-report Nr, 1270, Rim, 1954.

Burdon, D. J. 1959.: Spring al Hol. Inženjerski glasnik, vol. 96, Damask.

Dubertret, L. 1933.: L'hydrologie et apercu sur l'hydrographie de la Syrie at du Liban dans leurs realtions avec la géologie. RGPGD vol. 6., Paris.

Hamida, A.-R. 1962.: Hidrologija Sirije. Sveučilišna naklada, na arapskom, Damask.

Her, S. 1985.: Sirija. Ekonomska geografija. Sveučilišna naklada, na arapskom, Damask.

Khouri, J. et al. 1965.: Podzemne vode namjesništva Hassaka. Tehnički izvještaj. Ministarstvo poljoprivrede A. R. Sirije, rukopis u Arhivu Ministarstva, na arapskom, Damask.

Khouri, J., Rasoul Agha, W. 1976.: Projekt natapanja 1000 ha u okolici Kamišlija. Studija. Ministarstvo poljoprivrede A. R. Sirija, na arapskom, Damask.

Mardini, A. 1986.: Namjesništvo Hassaka. Vlastito izdanje, Damask.

Riđanović, J. 1993. Hidrogeografija. Školska knjiga, Zagreb.

Safadi, Š. 1960.: Vodni resursi Gornje Đezire. Inženjerski glasnik, vol. 102, na arapskom, Damask.

Safadi, Š., Morte, F. 1963.: Izvještaj za FAO. Ministarstvo poljoprivrede A. R. Sirije, rukopis u Arhivu Ministarstva, na arapskom, Damask.

Willcocks, W. 1937.: Raj između Adena i rijeke Jordan. Uprava natapanja Iraka, Bagdad. 
Baza podataka Hidrološke službe Sirije, Ministarstvo natapanja, Damask.

Bulgarian Agrocomplex Co. 1963.: Projekt natapanja i poboljšanja kvalitete tla u dolini rijeke Habur. Tehnički i ekonomski izvještaj. Studija Uprave za natapanje A. R. Sirije, Arhiv Ministarstva natapanja A. R. Sirije, na arapskom, Damask, Sofija.

Bulgarian Agrocomplex Co. 1976.: Hidrogeološka studija Gornje Đezire, područje od gornjeg Habura do Đakđaka. Ministarstvo natapanja A. R. Sirije, Arhiv Ministarstva natapanja A. R. Sirije, na arapskom, Damask, Sofija.

Bulgarian Agrocomplex Co. 1984.: Hidrogeološka studija Gornje Đezire, poriječje Rada. Ministarstvo natapanja A. R. Sirije, Arhiv Ministarstva natapanja A. R. Sirije, na arapskom, Damask, Sofija.

Interni izvještaji Ministarstva poljoprivrede Sirije iz 1986. i 1997. godine.

SUMMARY

\title{
River Regime Changes in the Upper Part of Khabour Catchment Area in North-Eastern Syria in the Second Half of the XXth Century - part I: Annual Runoff
}

\author{
Danijel Orešić, Georgos Bahnan
}

The research area is the Khabour river catchment area largely corresponding with Upper Jazirah region in north-eastern Syria in the Hasakah province in north-eastern Syria. It is a large basin between (South-eastern) Taurus Mountains (Turkey) in the North and Mountain range Abd al Aziz - Sinjar (mostly in Iraq) in the South. It is important to stress that in the Upper Jazirah syncline the strata are inclined towards South allowing ground water flow from the Taurus towards the basin up to the Abd al Aziz - Sinjar fault zone. Taurus Mountains are feeding Khabour and its main tributaries. Well developed upper part of the Khabour is thus corresponding with Upper Jazirah basin. In contrast, south of the basin, only Khabour - with no permanent tributaries - flows through the desert to join the river Euphrates.

The fertile upper part of the Khabour River attracted people. Khabour River (its very name meaning the source of fertility) was since ancient times important for irrigation of Upper Jazirah. Torrential tributaries from Taurus Mountains left fertile mud after every spring. However, most of the cities developed late, under French government. Mostly Arab immigration after WWII brought significant agricultural changes. Commercial agriculture started in 1950's, and with the government support and planning Al Hasakah province in the Upper Jazirah became by 1960's a true Syrian granary. However, this transformation was fast and largely poorly managed. In this semi-humid region water resources play a significant role in overall development. Water resources where overused, and this lead to changes in the natural surface runoff regime and groundwater level. Rivers annual discharges diminished and river regimes changed. This was becoming more and more obvious since the seasonal tributaries of the Khabour river in the more humid northern part of the research area stayed dry for a longer and longer period. It is known that tributaries Jarjab and Zargan were formerly permanent rivers. Since 1990's they dried up for a longer time and from 1995 for several 
Danijel Orešić, Georgos Bahnan - Promjene režima otjecanja tekućica u gornjem dijelu poriječja Habura u sjeveroistočnoj Siriji u drugoj polovici XX. st. - dio I: godišnji protoci

months and now they are seasonal river that regularly dry up for three to four months. The reason for this is primarily to be found in lowering of water table due to increased number of diesel-powered water pumps used in irrigation (Bahnan, 2003). Interesting case in the research area is also the case of Rad River depression (about $60 \mathrm{~km}$ long and 5-20 km wide, roughly inside $350 \mathrm{~m}$ contour) were up to 1980's there was a permanent swamp. After agricultural development and dams constructed on some northern tributaries of Rad River the swamp became periodic and salty.

This paper deals with changes in mean and total annual runoff $\left(\mathrm{m}^{3} / \mathrm{s}\right)$ primarily on Khabour River, for which the data are available for a longer period on several water gauge stations. The oldest three water gauge stations on Khabour River were established in 1931, during French government, and three more where established in 1942. In the catchment area some more were established from 1950 's up to 1970's. However, during this time water gauge stations were also abandoned and/or measurements were not taken regularly. All in all today there are only six stations in upper part of Khabour cathment area, and on two of them there is less than 10 years of measurement. There are no automatic water level recorders at all. On some important tributaries there are no water gauge stations. Reliable and regular measurements in the research area are taken on the water gauge stations Ras al Ain (1943-2000), Tal Tamer (1943-2000) Hasakah (1943-2000) and on Khabour River and on Khamishli (1961-2001) station on Jaghjagh River.

From the data presented from the period 1943-2001 it is obvious that there is a significant lowering of the annual runoff on water gauge stations on Khabour River and its tributaries, particularly after 1970's. The main reason for this negative change is partly uncontrolled use of ground-water and river-water in agriculture. Most of the diesel-powered water pumps were introduced in 1980's, and the number of agricultural wells grew especially fast after 1985. Also, more and more cotton was introduced, which has a high water demand. The water is pumped from underground, but also from Khabour especially around the provincial capital Hasakah. Also the discharge of Kahbour's main tributary Jaghjagh diminished as its cathment area became intensely populated and agriculturally very productive after 1980's. This can explain a rather faster diminishing of runoff on Hasakah station on Khabour river, situated bellow the mouth of Jaghjagh. Upstream of Tal Tamer some of the Khabour waters are taken through a channel opened in 1996 to feed the artificial lakes Western and Eastern Hasakah important for irrigation and water supply of the city Hasakah. This changes the natural river regimes of Khabour at Tal Tamer and Hasakah stations. It is important to stress that the pumping of water intensified in latest years even in the Ras al Ain area, where there are main springs that feed the Khabour River. Comparison of annual precipitation (meteorological station Ras al Ain) and mean annual runoff (water gauge station Ras al Ain / Khabour) in period 1975-2000 showed that the mean runoff is diminishing from around 50 to only around $10 \mathrm{~m}^{3} / \mathrm{s}$, and such negative trends are not seen for annual precipitation (nor on other meteorological stations; Bahnan, 2003). This is worrying since Ras al Ain is the main source of Khabour River. It is also very probable that the base flow is influenced by similar agricultural development in Turkey. Important question is the available ground-water from the middle Eocene limestone aquifer, since it is feeding the Ras al Ain (and other important) springs, main source of Khabour river, the economic backbone of the region. The Eocene aquifer largely feeds itself in Turkey (Taurus Mountains), and drains easily, so there is a clear necessity for an agreement on water management of this source between Turkey and Syria.

The comparison of mean and total runoffs on Khabour River from periods 1961-1980 and 19812000 confirms the seriousness of the water overuse. In the period 1981-2000 the annual runoff of Khabour River practically halved in comparison to the earlier twenty-year period. This is confirming some earlier warnings from the studies ordered by Syrian Ministry of Agriculture.

In conclusion, in this semi-humid region water resources play a significant role in overall development. Water resource management was poor and in the future its promotion is necessary for the sustainable development of the region. The upper part of the Khabour catchment area is an important 
Syrian cotton and wheat production area. Further population growth and successful agricultural production depend on modern water resources management. Excessive and largely unplanned use of water resources (as in the past) from both underground and overland sources may lead to problems well known elsewhere in the world, up to permanent loss of the aquifers, i.e. ground-water reserves which would cause enormous damage not only for the region but for the whole of Syria as well.

Primljeno (Received): 11 - 11 - 2004

Prihvaćeno (Accepted): 11 - 5 - 2005

Danijel Orešić, dr. sc. docent Geografski odsjek, Prirodoslovno-matematički fakultet, Marulićev trg 19, 10000 Zagreb Hrvatska/Croatia

E-mail: doresic@geog.pmf.hr

Georgos Bahnan, Ph. D.

Department of Geography, Faculty of Arts

Al-Mezzeh, Damascus, Syria

E-mail: GeorgBahnan@hotmail.com

Tel: 0096352750079 